\title{
Gliosarcoma Transforming from Giant Cell Glioblastoma: A Case Report and Review of the Literature
}

\author{
Dev Hücreli Glioblastomdan Transforme Olan Gliosarkom: Olgu Sunumu ve \\ Literatür Taraması \\ (1) Elife Kımıloğlu, (1) Havva Ceren Ağcakoyunlu, (D) Muhittin Emre Altunrende*, \\ (1) Osman Akdemir** \\ University of Health Sciences, Gaziosmanpaşa Taksim Training and Research Hospital, Clinic of Pathology, Istanbul, Turkey \\ *University of Health Sciences, Gaziosmanpaşa Taksim Training and Research Hospital, Clinic of Neurosurgery, Istanbul, Turkey \\ ** University of Health Sciences, Haseki Training and Research Hospital, Clinic of Neurosurgery, Istanbul, Turkey
}

Abstract

Giant cell glioblastoma and gliosarcoma are rare histological variants of glioblastoma multiforme. These are WHO Grade IV astrocytic tumors. While giant cell glioblastoma can be seen at younger age, gliosarcoma typically presents at age 40-60 years. Gliosarcoma has a worse prognosis than giant cell glioblastoma. Here, we report a case of giant cell glioblastoma transforming to gliosarcoma and review of the literature.

Keywords: Giant cell glioblastoma, gliosarcoma, glioblastoma multiforme, transformation

Öz

\begin{abstract}
Dev hücre glioblastom ve gliosarkom, glioblastoma multiformenin nadir histolojik varyantıdır. Bunlar WHO Sınıf IV astrositik tümörlerdir. Dev hücreli glioblastom yaşamın erken dönemlerinde görülebilmesine karşın, gliosarkomun yaş ortalaması 40-60 yıldır. Gliosarkom, dev hücre glioblastomdan daha kötü prognoza sahiptir. Biz dev hücre glioblastomadan transforme bir gliosarkom olgusunu ve glial tümörlerde transformasyonla ilgili literatür taramasını sunduk.
\end{abstract}

Anahtar Sözcükler: Dev hücre glioblastom, gliosarkom, glioblastoma multiforme, transformasyon

\section{Introduction}

Giant cell glioblastoma (GCG) and gliosarcoma (GS) are rare histological variants of IDH-wildtype glioblastoma according to the recent WHO Classification of Central Nervous Systems Tumours (2016) (1). While GS accounts for $2 \%$ of all glioblastoma, GCG accounts for less than $1 \%$. GCG can be seen at earlier ages, even in children, compared to conventional glioblastoma multiforme (GBM). Despite its high nuclear grade GCG has been reported to have better prognosis than conventional glioblastoma (2). GCG and GBM have similar clinical presentation and tumor location (2). However, GCG is more circumscribed than GBM in radiological imaging. GCG is characterized by numerous multinucleated giant cells, fusiform small syncytial cells and prominent reticulin network. The giant cells have angulated nuclei, prominent nucleoli and cytoplasmic inclusion. Also, perivascular accumulation, termed as pseudorosette, atypical mitoses and necrosis may be seen. Giant cells have positive reaction with GFAP and S-100. Ki-67 proliferation index is similar to conventional GBM. GS was first identified by Strobe in 1895 . Fiegen reported more extensive histological analyses in 1955. GS is usually located at the cerebral hemispheres like GBM and usually present at 40-60 years of age. Despite rarely,

Address for Correspondence/Yazışma Adresi: Muhittin Emre Altunrende, University of Health Sciences, Gaziosmanpaşa Taksim Training and Research Hospital, Clinic of Neurosurgery, Istanbul, Turkey

E-mail: mealtunrende@msn.com ORCID: orcid.org/0000-0003-3345-5821

Received/Geliş Tarihi: 13 December 2018 Accepted/Kabul Tarihi: 04 January 2019

This study was presented in "the 30th European Congress of Pathology" as an oral presentation.

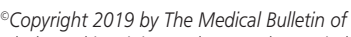
istanbul Haseki Training and Research Hospital The Medical Bulletin of Haseki published by Galenos Yayınevi. ${ }^{\circledR}$ Telif Hakkı 2019 İstanbul Haseki Eğitim ve Araştıma Hastanesi Haseki Tıp Bülteni, Galenos Yayınevi tarafından yayınlanmıştır. 
it may be seen also in children. GS has biphasic neoplastic differentiation. Glial component of GS resembles ordinary glioblastoma and mesenchymal component usually resembles fibrosarcoma or malignant fibrous histiocytoma, but it may be seen like chondrosarcoma, osteosarcoma, leiomyosarcoma, liposarcoma or rhabdomyosarcoma $(3,4)$. In one case, primitive neuroectodermal tumor-like differentiation was reported (3). While glial component of GS has positive reaction with glial fibrillary acidic protein (GFAP), the mesenchymal component has positive reaction with vimentin. The mesenchymal component was initially considered as malignant transformation of proliferating blood vessels (5). However, recent studies showed that both of them were similar in cytogenetic and molecular evidence and also in monoclonal origin GCG and GS are WHO Grade IV astrocytic tumors. GS has worse prognosis than GCG.

\section{Case}

A 48-year-old woman presented with headache, weakness of the left leg and facial asymmetry. On physical examination, the patient was conscious, had right peripheral fasial paralysis and muscle strength in the left leg and armwas 2/5. Contrast-enhanced magnetic resonance imaging of the brain showed a cystic, irregular enhancing mass in the anterior subcortical white matter of the right parietal lobe. This mass was shifting to the right (Figure 1). Microscopic examination of this lesion showed cells with large hyperchromatic, multinuclear or multiloculated nuclei and eosinophilic cytoplasm often showing prominent pleomorphism dispersed in a necrotic background. These cells showed strong reaction with GFAP and Ki-67 proliferation index was $21 \%$. Based on these findings, the diagnosis of GCG was established (Figure 2). After surgery, the patient received radiotherapy. After five months of the initial diagnosis, the patient was back with similar symptoms. Radiological examination showed a lesion measuring approximately 4 $\mathrm{cm}$ in diameter in the right frontal lobe and prominent edema around this mass (Figure 3). In histological examination, there were pleomorphic, hyperchromatic glial cells like conventional glioblastoma and spindle cells with hyperchromatic, oval nuclei and eosinophilic cytoplasm arranged in both fascicles and whorl pattern in the neuropil matrix. Glial component showed GFAP and S-100 expression; mesenchymal component showed expression with vimentin and increased reticulin fibers in mesenchymal component (Figure 4). Ki-67 proliferation index was $35 \%$. Based on these findings, we reported it as GS. After another four months, the patient presented with confusion. Radiological examination revealed a $6.5 \times 4$ $\mathrm{cm}$ mass in the former operation area and multiple lesions in the posterior fossa, temporal lobe and cerebellopontin region. Re-excised specimen was histopathologically compatible with GS.

Written informed consent was obtained from the patient and the next of kin for publication of this case report and accompanying images.

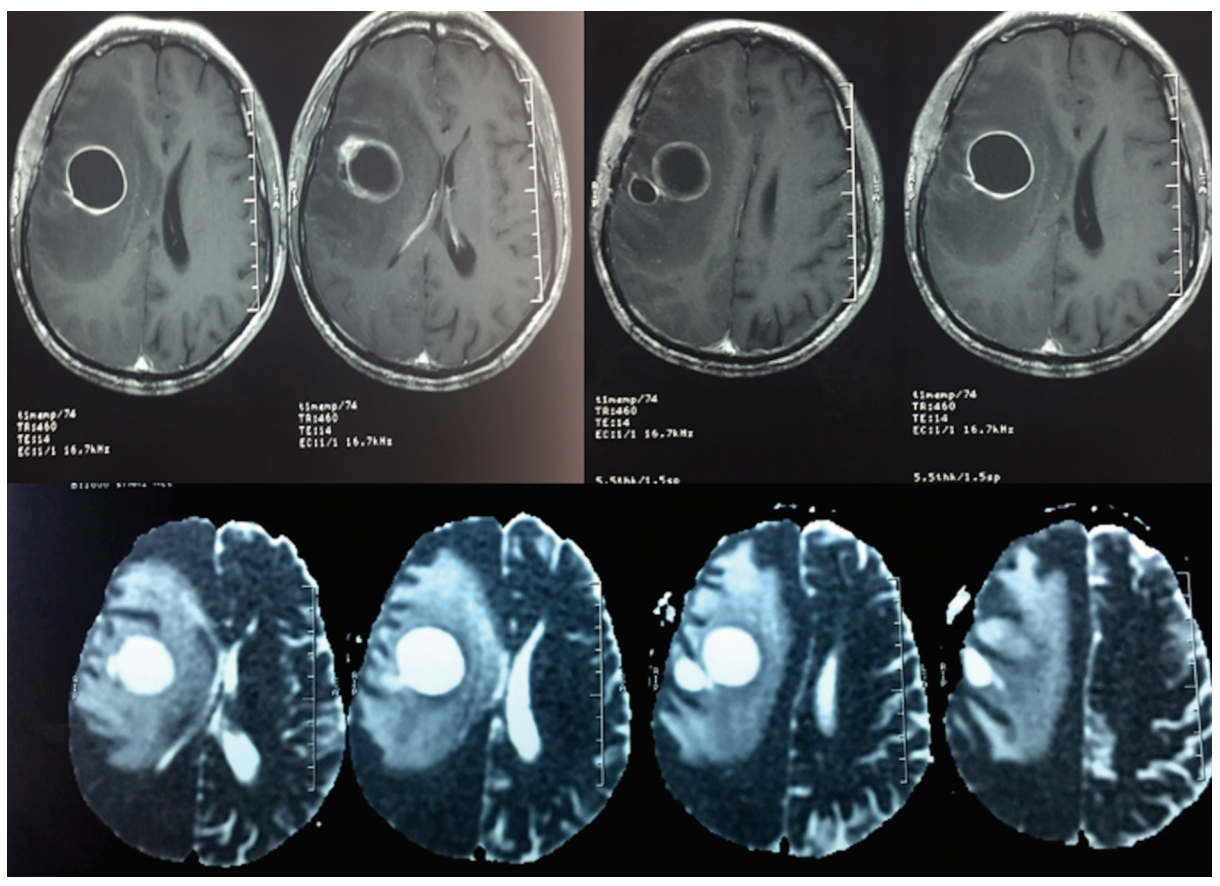

Figure 1. Brain contrast-enhanced MRI showing a mass with irregular enhancement in the right parietal lobe MRI: Magnetic resonance imaging 


\section{Discussion}

GCG is a rare variant of all glioblastomas. GCG can also be seen in children despite average age of onset is 44 years. Its male-to-female ratio is 1.6/1. Estimated median survival in patients with GCG is about 4-18

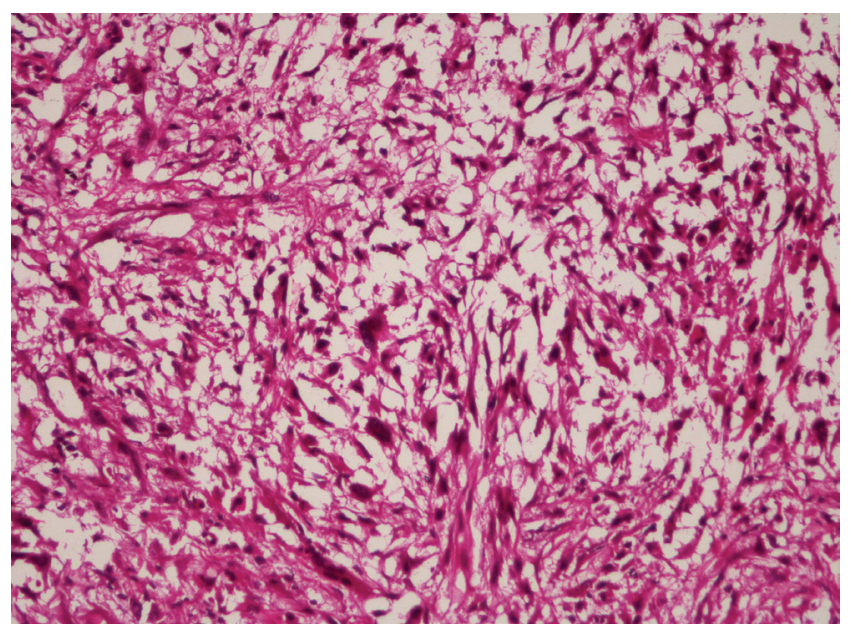

Figure 2. Gliomatous component as glioblastoma (H\&E x200)

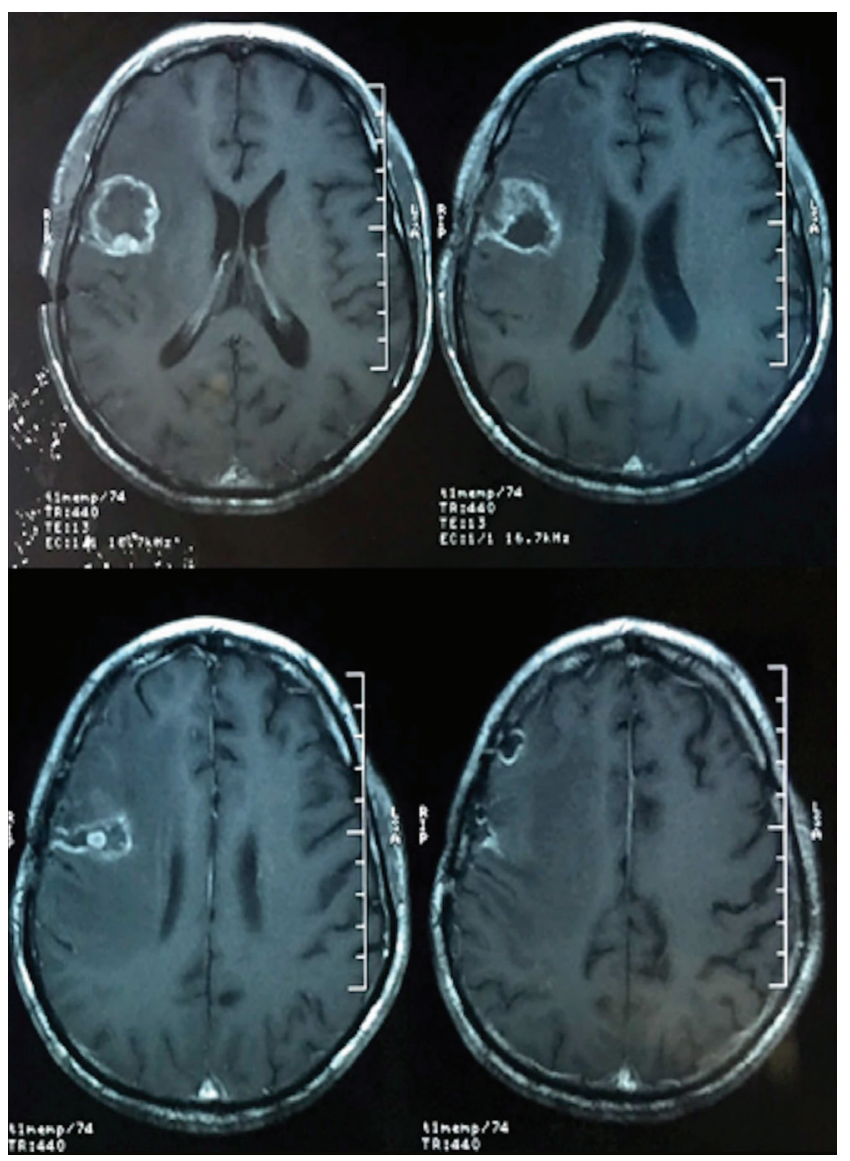

Figure 3. The lesion in the right frontal lobe and prominent edema (Transformation gliosarcoma) months and is relatively long compared to conventional glioblastoma. Typically, GCG and GS exhibit TP53 and PTEN mutations. While GCG does not show EGFR mutation, glial component of GS infrequently may have EGFR mutation. There is TP53 mutation in both of components of GS. These results suggested that the sarcomatous component of GS is an advanced dedifferentiated glial form with GFAP loss of appendage. Epithelial-mesenchymal transition model in glioblastoma may have an explanatory role in glial-mesenchymal transformation. GCG is a IDH-wild type glioblastoma, whereas IDH1/2 mutation may occur in $5 \%$ of cases. GS is frequently located in the cerebral hemispheres, especially temporal lobe, followed by frontal lobe, but posterior fossa, spinal cord, intraventricular area, pineal gland, and pyterigopalatine fossa as extracranial location have also been reported (6). Although GS is generally seen as unifocal mass, there has been one reported case of multifocal GS (7). In our case, multifocal GS was seen on the second recurrence. The most common symptoms are seizure, neurological deficits and headache. Secondary GS is a condition identified in patients with prior glioblastoma treated with radiotherapy or GSs transformed from a lowgrade glioma in those who received no treatment (8). The average survival is 6-14.8 months and the longest reported survival is 10 years. Sixty-two cases of secondary glioblastoma have been reported in the literature (9). Fifty-three of these cases were primary glioblastoma in patients who received radiotherapy. One of them was treated only with chemotherapy, one with gamma knife

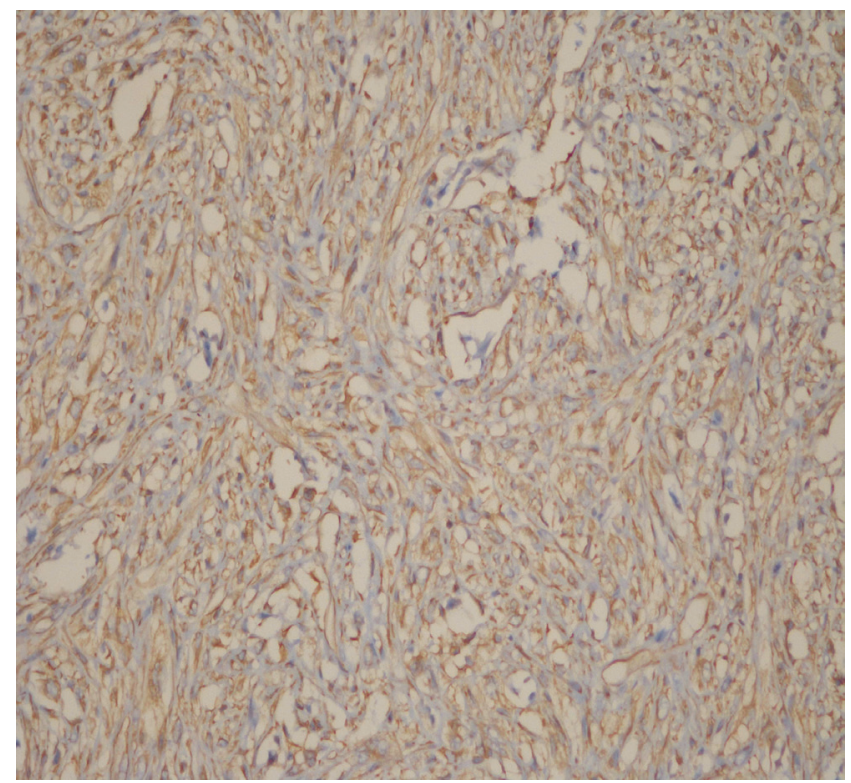

Figure 4. Sarcomatous component shows expression with vimentin (IHC x400) IHC: Inner hair cell 
radiosurgery and the other received no treatment after surgery (10-12).

The first diagnoses of the 62 cases were reported as two anaplastic astrocytomas, two pilocytic astrocytomas, one medulloblastoma, one oligodendroglioma and one vestibular schwannoma. In the majority of the cases, male gender was favored. Mean age of the secondary GSs in the literature was 48.7 years. There is no significant difference between primary and secondary GS in location, radiological imaging and clinical symptoms (12). Only one case of GCG transformation to GS has been reported and it has recurrence time of 27.2 months. In our case, time to recurrence was shorter. Secondary GS has shorter survival time and worse prognosis than primary GS. In recent years the frequency of secondary GS increased (13). The reason for this increase can be aggressive treatment modalities for glioblastomas and longer survival time in patients who receive treatment. GS often metastasizes to the liver and lungs. However, the incidence of metastasis remains constant.

\section{Conclusion}

GCG and GS are rare tumors. GSs transforming from low-grade glial tumors and occurring after radiotherapy are thought to develop with different mechanisms. The data in this field is still insufficient. More molecular and genetic analysis should be applied in the future.

\section{Authorship Contributions}

Concept: E.K. Design: M.E.A. Data Collection or Processing: H.C.A. Analysis or Interpretation: E.K. Literature Search: O.A. Writing: E.K., M.E.A.

Conflict of Interest: No conflict of interest was declared by the authors.

Financial Disclosure: The authors declared that this study received no financial support.

\section{References}

1. Louis DN, Ohgaki H, Wiestler OD, Cavenee WK. The 2016 World Health Organization Classification of Tumours of the Central Nervous Systems. 4. Edition.International Agency for Research on Cancer (IARC)
2. Zhen H, Yang D, Shen J, et al. Primary gliosarcoma with longsurvival: report of two cases and review of literature. Int J Clin EXP Patho 2014;7:6323-32.

3. Yoshida $Y$, Ide $M$, Fujimaki $H$, et al. Gliosarcoma with primitive neuronal, chondroid, osteoid and ependymal elements. Neuropathology 2018.

4. Sugita $Y$, Terasaki M, Tanigawa $K$, et al. Gliosarcomas arising from the pineal gland region: uncommon localization and rare tumors. Neuropathology 2016;36:56-63.

5. Deb P, Sharma MC, Chander B, Mahapatra AK, Sarkar C. Giant cell glioblastoma multiforme: report of a case with prolonged survival and transformation to gliosarcoma. Childs Nerv Syst 2006;22:314-9.

6. Mason A, Villavicencio AT, Nelson EW, Forsythe RC, Burneikiene S. Post-treatment gliosarcoma extension into the pterygomaxillary fossa: Literature review and case report. Cureus 2016;8:e700.

7. Pakos EE, Goussia AC, Zina VP, Pitouli EJ, Tsekeris PG. Multifocal gliosarcoma: a case report and review of the literature. J Neurooncol 2005;74:301-4.

8. Kobayashi T, Sakai K, Tada T, et al. Gliosarcoma arising from a fibrillary astrocytoma. J Clin Neurosci 2011;18:1251-4.

9. Okami N, Kawamata T, Kubo 0, Yamane F, Kawamura H, Hori T. Infantile gliosarcoma: a case and a review of the literature. Childs Nerv Syst 2002;18:351-5.

10. Cheonga J.H, Kim C.H, Kim J.M, Oh Y. Transformation of intracranial anaplastic astrocytoma associated with neurofibromatosis type I into gliosarcoma: Case report. Clin Neurol Neurosurg 2010;112:701-6.

11. Malde R, Jalali R, Muzumdar D, Shet T,Kurkure P. Gliosarcoma occurring 8 years after treatment for a medulloblastoma. Childs Nerv Syst 2004;20:243-6.

12. Yasuda $T$, Nitta $M$, Komori $T$, et al. Gliosarcoma arising from oligodendroglioma, IDH mutant and $1 \mathrm{p} / 19 \mathrm{q}$ codeleted. Neuropathology 2018;38:41-6.

13. Cachia D, Kamiya-Matsuoka C, Mandel JJ, etal.Primary and secondary gliosarcomas: clinical, molecular and survival characteristics. J Neurooncol 2015;125:401-10. 